\title{
Thixoforming of an Al-Si-Zn-Mg Alloy - Thermodynamic Characterization, Microstructural Evolution and Rheological Behavior
}

\author{
André Victor Rodrigues Dantas ${ }^{a}$, Gabriela Lujan Brollo ${ }^{a}$, Daimer Velasquez Tamayo ${ }^{b}$, \\ Eugênio José Zoqui * * (D)

\begin{abstract}
${ }^{a}$ Universidade Estadual de Campinas (UNICAMP), Faculdade de Engenharia Mecânica, Departamento de Engenharia de Manufatura e Materiais, 13083-860, Campinas, SP, Brasil

${ }^{b}$ Universidad de Oriente, Facultad de Ingeniería Mecánica, Santiago de Cuba, Cuba
\end{abstract}

Received: July 15, 2020; Revised: November 12, 2020; Accepted: January 14, 2021

\begin{abstract}
Al-Si-Zn-Mg quaternary alloys represent a potential range of feedstock's for semisolid processing (SSM) that combine the advantages of the thixoforming process with the possibility of heat treatment to improve mechanical performance. In this work, the suitability of the $\mathrm{Al}-5 \mathrm{wt} \% \mathrm{Si}-5 \mathrm{wt} \% \mathrm{Zn}-0.5 \mathrm{wt} \% \mathrm{Mg}$ alloy for use in thixoforming was assessed by thermodynamic characterization and by an analysis of its microstructural evolution and rheological behavior. Thermodynamic analysis was performed by numerical simulation and by application of the differentiation method to Differential Scanning Calorimetry (DSC) curves for heating cycles up to $700{ }^{\circ} \mathrm{C}$ at 5 and $25^{\circ} \mathrm{C} / \mathrm{min}$. Microstructural evolution during partial melting at $594^{\circ} \mathrm{C}$ for $0,30,60$ and $90 \mathrm{~s}$ and the corresponding rheological behavior were analyzed. The findings indicate good agreement between the thermodynamic behavior predicted by DSC and Calculation of Phase Diagrams (CALPHAD) and the data obtained from semisolid forging. Although the alloy has a coarse microstructure $\left(\mathrm{G}_{\mathrm{S}} \max =200 \mu \mathrm{m}\right)$, its rheological behavior is appropriate for thixoforming $\left(\sigma_{\max }=1.06 \mathrm{MPa}\right.$ and $\left.\mu_{\max }=1.79 \times 10^{4} \mathrm{~Pa} . \mathrm{s}\right)$, indicating that the microstructure only plays a secondary role in determining viscosity when enough liquid $\left(f_{1}=0.63\right)$ is present in the slurry to enhance the flow. The alloy is suitable for use as raw material for semisolid processing.
\end{abstract}

Keywords: Thixoforming, semisolid materials, Calphad, Al-Si-Zn-Mg alloy, microstructure, rheology.

\section{Introduction}

Although semisolid processing technology (SSM) has been in use for approximately 40 years, the range of alloys used in thixoforming processes is still limited mainly to the aluminum alloys A356 and $357^{1}$, as well as 355 and $319 \mathrm{~S}^{2,3}$. Al-Si cast alloys ( 3 xx.x series) are suitable for thixoforming operations because $\mathrm{Si}$ increases the fluidity of the alloy, reduces contraction during cooling and, at low contents, improves machinability ${ }^{2-6}$. However, Si decreases ductility ${ }^{6,7}$. On the other hand, 7xxx series wrought alloys, which contain a combination of $\mathrm{Zn}$ and $\mathrm{Mg}$, have high impact resistance and tensile strength and excellent ductility as a result of the formation of hardening precipitates after precipitation heat treatment ${ }^{6}$. The combined use of these elements (the Al-Si$\mathrm{Zn}-\mathrm{Mg}$ system) for SSM processing applications has been little studied ${ }^{3}$, yet such alloys represent a potential range of raw materials that combine the advantages of thixoforming with the possibility of heat treatment after forming for improved mechanical performance.

It is crucial in thixoforming that the semisolid slurry contain refined, spheroidal solid particles in the liquid to ensure a thixotropic rheology, which is required for smooth, laminar die-filling ${ }^{2,8,9}$. Factors such as the microstructure of the raw material, heating rate, processing temperature,

*e-mail: zoqui@fem.unicamp.br soak time and shear rate during forming play a crucial role in determining the microstructure and rheology of the semisolid slurry. Furthermore, thermodynamic stability, which depends on the chemical composition of the alloy and the kinetics of the thixoforming process, is essential to achieve a stable solid-liquid mixture, i.e., a controllable microstructure, rheology and liquid fraction in the presence of temperature variations during formation, and so ensure that SSM processing is reproducible $\mathrm{e}^{2-5,8-17}$.

The Semisolid Processing Group in the Faculty of Mechanical Engineering at the State University of Campinas (UNICAMP) has undertaken a range of research to increase the number of potential alloys with the required features for semisolid state processing. This research includes studies of systems such as Al-Si, Al-Si-Cu, Al-Si-Mg, Al-Si-Zn and $\mathrm{Fe}-\mathrm{C}-\mathrm{Si}$ using many preprocessing routes, including electromagnetic stirring (EMS), ultrasound stirring (UST) and equal channel angular pressing (ECAP) $)^{4,16,18-24}$. The present study represents a new attempt to expand the range of feedstocks suitable for SSM processing and focuses on the combination of $\mathrm{Al}, \mathrm{Si}, \mathrm{Zn}$ and $\mathrm{Mg}$ as alloying elements. The thermodynamic stability, microstructural evolution during partial melting and rheological behavior during open-die thixoforging of the semisolid slurry are analyzed. As the focus of the study is the processing of this type of alloy, 
the mechanical properties and microstructure of the final thixoformed product are not discussed here but will form the subject of a future study.

\section{Experimental Procedure}

The chemical composition of the Al-Si-Zn-Mg alloy studied here is shown in Table 1 and was determined with a BILL OES optical spectrometer. The alloy was manufactured from a combination of A356, Mg-10wt $\% \mathrm{Al}$ and commercially pure $\mathrm{Al}$ and $\mathrm{Zn}$. It was melted and poured at $650{ }^{\circ} \mathrm{C}$ into a semi-continuous casting system consisting of a water-cooled copper mold (30 mm D x $250 \mathrm{~mm} \mathrm{~L}$ ). Grain refinement was achieved by adding an Al-5wt.\%Ti-1wt.\%B master alloy until the liquid alloy had a Ti content of $0.2 \mathrm{wt} . \%$ and applying magnetic stirring to the solidifying billets with a $2 \mathrm{~kW} 14 \mathrm{G}$ induction coil around the casting die. Obtaining the raw material followed the experimental procedure used in previously published works ${ }^{20}$, which indicated the optimum amount of grain refiner to be added, as well as the level of magnetic field, which would generate the most refined microstructure possible.

Thermodynamic simulation was performed with Calculation of Phase Diagrams (CALPHAD) software Thermo-Calc ${ }^{\circledR}$ to generate the phase diagram at thermodynamic equilibrium and the $f_{l}$ vs. $T$ curve under the non-equilibrium Scheil condition $^{4,15,16}$ for the alloy. The results of this simulation were used as reference for the experimental curves. The percentages of $\mathrm{Al}, \mathrm{Si}, \mathrm{Zn}, \mathrm{Cu}, \mathrm{Mg}, \mathrm{Ni}, \mathrm{Fe}$ and $\mathrm{Ti}$ were considered in the simulation. The TTAL5 database was used.

Differential thermal analysis to determine the experimental $f_{l}$ vs. $T$ curve for the alloy was performed with a NETZSCH STA 409C Differential Scanning Calorimeter (DSC) system. The STA 409C has a resolution of 720,000 digits, data acquisition rate of 20 data $\mathrm{s}^{-1}$ and sensitivity of $710 \mathrm{mV}$, giving a measurement accuracy of more than $0.5^{\circ} \mathrm{C}$. The cylindrical DSC sample ( $\max .5 \mathrm{~mm} \mathrm{D}$ x $3 \mathrm{~mm} \mathrm{H}$ ) weighed approximately $20 \mathrm{mg}$. The sample was heated to $700{ }^{\circ} \mathrm{C}$ at 5 and $25^{\circ} \mathrm{C} / \mathrm{min}$. Heat flow rate (here called HFR) and temperature were monitored with thermocouples so that $H F R$ vs. $T$ curves could be generated. All the DSC tests were carried out with the same specimen to prevent differences in chemical composition along the billet influencing the results. Prior to data acquisition, the DSC sample was heated to $700{ }^{\circ} \mathrm{C}$ and then cooled to room temperature at the lowest rate $\left(5^{\circ} \mathrm{C} / \mathrm{min}\right)$, also to guarantee chemical homogeneity along the specimen. The differentiation method (DM) ${ }^{25,26}$ was applied to the DSC data to determine the temperatures corresponding to the solidus, liquidus, main eutectic knee and limits of the thixoforming working window. To this end, the HFR data were differentiated with respect to temperature, giving the variation in HFR with temperature during heating/ cooling ( $d H F R / d T$ vs. $T$ curves). The $f_{l} v s . T$ relationship was determined with NETZSCH Protheus ${ }^{\circledR}$ thermal analysis software by applying the Flynn method ${ }^{27}$ of integration of partial areas under the DSC curves. Origin ${ }^{\circledR}$ software was used for direct differentiation of the $f_{l}$ vs. $T$ curve to obtain the $d f / d T$ (sensitivity) vs. $T$ curve. This way the solidus temperature $\left(\mathrm{T}_{\text {solidus }}\right)$, the liquidus temperature $\left(\mathrm{T}_{\text {liquidus }}\right)$, the eutectic melting/solidification temperature $\left(T_{\text {knee }}\right)$ as well as the lowest and higher temperature for semisolid processing $\left(\mathrm{T}_{\text {SSMI }}\right.$ and $\mathrm{T}_{\text {SSMF }}$ ) were determined.

Note that, one of the main concepts used in semisolid processing is the sensitivity $\left(\mathrm{df}_{1} / \mathrm{dT}\right)^{4,15,16,25,26}$, which is nothing more than the derivative curve of the liquid (or solid) fraction as a function of temperature, and represents how much, in proportional terms, the amount of liquid or solid present may vary depending on the temperature fluctuations that is common in all the metallurgical processes. Normally, the sensitivity is evaluated for a desired solid / liquid fraction, that is, for a target temperature. If the sensitivity to the desired condition is low $\left(\mathrm{df}_{1} / \mathrm{dT}<0.03{ }^{\circ} \mathrm{C}\right)^{15}$, the process is controllable. If the sensitivity is too high at the desired solid fraction, the process is difficult to control.

Heat treatment to analyze the microstructural evolution of the Al-Si-Zn-Mg alloy in the semisolid state was performed with cylindrical samples $(30 \mathrm{~mm} \mathrm{D} \mathrm{x} 30 \mathrm{~mm} \mathrm{H})$ taken from the as-cast billets. The samples were heated to $594{ }^{\circ} \mathrm{C}$ at a heating rate of approximately $100^{\circ} \mathrm{C} / \mathrm{min}$. After being kept at the holding temperature for $0,30,60$ or $90 \mathrm{~s}$, the samples were immediately quenched in water. The temperature of the sample was monitored with a thermocouple placed in a hole drilled in the upper flat surface of the cylinder. The position of the thermocouple tip corresponded to the geometrical center of the sample. A Norax $8 \mathrm{kHz} 25 \mathrm{~kW}$ induction furnace with a temperature accuracy of within $\pm 2{ }^{\circ} \mathrm{C}$ was used.

Microstructural homogeneity over the cross section of the billets was achieved along approximately $80 \%$ of their length. Roughly $10 \%$ of the length had coarser grains because of the lower heat flow in the center of the billet and a further $10 \%$ of the length ( $5 \%$ at each end) had smaller grains because these regions came into contact with the water-cooled surface during casting. The micrographs used in this work were therefore taken from the two intermediate homogeneous regions between the center and ends.

The microstructures of the as-cast and heat-treated samples were characterized by conventional $\mathrm{B} \& \mathrm{~W}$ and polarized-light color microscopy using a Leica DM ILM optical microscope. For color microscopy, the samples were etched in a $0.5 \%$ HF solution for $3 \mathrm{~s}$ and then etched electrolytically in $1.8 \%$ HBF4 at $0.6 \mathrm{~A}$ and $30 \mathrm{~V}$ for $360 \mathrm{~s}$ under stirring. Polarizing filters were used to obtain color images of the grains so that grains with the same crystal orientation had similar colorings. Observations were performed in the longitudinal direction of the billets. Each primary phase observed separately in a conventional B\&W micrograph is referred to here as a "globule". It is assumed that adjacent globules with the same coloring in a polarized optical micrograph are part of the same interconnected "skeleton" structure in 3D. This structure is represented by the grain observed in the

Table 1. Chemical composition of the Al-Si-Zn-Mg alloy studied here as measured by OES.

\begin{tabular}{cccccccccc}
\hline Element & $\mathrm{Si}$ & $\mathrm{Zn}$ & $\mathrm{Mg}$ & $\mathrm{Fe}$ & $\mathrm{Cu}$ & $\mathrm{Mn}$ & $\mathrm{Res}$ \\
\hline Wt.\%** & $4.81 \pm 0.2$ & $5.03 \pm 0.3$ & $0.54 \pm 0.05$ & 0.19 & 0.08 & 0.06 & 0.18 & $\mathrm{Bal}$ & \\
\hline
\end{tabular}

* The sum of residual elements, such as $\mathrm{Cr}$, Sn and Ti. **Unless otherwise indicated, standard deviation $< \pm 0.02$. 
2D images ${ }^{28,29}$. A complete explanation of the relationship between grain and globule can be found in an earlier work ${ }^{30}$.

Grain size $\left(\mathrm{G}_{\mathrm{S}}\right)$ and globule size $\left(\mathrm{GL}_{\mathrm{S}}\right)$ were determined using the Heyn intercept method ${ }^{31}$. The shape factor (circularity, C) was calculated using Image-J ${ }^{\circledR} 1.40 \mathrm{~g}$ software and the equation $\mathrm{C}=(4 \pi \mathrm{A}) / \mathrm{P}^{2}$, where $\mathrm{A}$ is the area and $\mathrm{P}$ the perimeter $(\mathrm{C}=1$ : sphere; $\mathrm{C} \rightarrow 0$ : needle $)$. Particles smaller than $10 \mu \mathrm{m}$ were not considered in the calculation. Statistical distributions for the microstructural parameters were determined because of the large standard errors. The statistical populations (n) analyzed were approximately $\mathrm{n}=27$ for $\mathrm{G}_{\mathrm{s}}, \mathrm{n}=27$ for $\mathrm{GL}_{\mathrm{s}}$ and $\mathrm{n}=2000$ for circularity. The standard error was obtained by dividing the standard deviation by $\sqrt{n}_{\mathrm{n}}$ for each parameter.

Compression tests were performed on the alloy in the semisolid state using an instrumented mechanical press, which also works as a compression rheometer ${ }^{32}$. The thixoforming samples $(30 \mathrm{~mm} \mathrm{D} \times 30 \mathrm{~mm} \mathrm{H})$ were taken from the as-cast billets and heated to the semisolid state in the same manner and under the same conditions as in the thermal-treatment experiments. After the target temperature had been reached and the holding time had elapsed, an engineering strain of 0.8 was imposed at a strain rate of approximately $4.2 \mathrm{~s}^{-1}$. The output data from the mechanical press were used to calculate the engineering stress ( $\sigma$ in $\mathrm{MPa}$ ) vs. engineering strain $(e)$ curve as well as the apparent viscosity ( $\mu$ in Pa s) vs. shear rate $\left(\dot{\gamma}\right.$ in $\left.\mathrm{s}^{-1}\right)$ curve based on the following equations $\mathrm{s}^{32,33}$ :

$e=1-\frac{h}{h o}$

$\sigma=\frac{F h_{0}}{V}(1-e)=\frac{F h}{V}$

$\mu=-\frac{2 \pi F h^{5}}{3 V^{2}\left(\frac{d h}{d t}\right)}$

$\dot{\gamma}=-\left(\sqrt{\frac{V}{\pi}}\right)\left(\frac{\left.\frac{d h}{d t}\right)}{2 h^{2,5}}\right.$ where $F$ is the load, $h$ and $h_{0}$ are the instantaneous and initial heights of the sample, respectively, $V$ is the constant volume of the sample and $t$ is the time.

\section{Results and Discussion}

\subsection{Thermodynamic characterization}

Figure 1 shows the phase diagram at thermodynamic equilibrium for the Al-(0-14wt.\%)Si-5wt.\%Zn-0.5wt.\%Mg system obtained using Thermo-Calc ${ }^{\circledR}$. The vertical line (white) corresponds to the Si content in the alloy studied (5 wt.\%). The colored phase fields are described on the right of the diagram. The uncolored areas lie outside the scope of this study. Solidification of the Al5Si5Zn0.5Mg alloy begins with the formation of a face-centered cubic matrix of pure aluminum $\left(\mathrm{Al}_{\mathrm{FCC}}\right)$, followed by secondary Fe-rich $\mathrm{AlFeSi}-\beta$ and Si-rich eutectic phases formed around the primary grains. With further cooling, the $\mathrm{Al}_{\mathrm{FCC}}$ turns into an Al-rich solid solution (Al- $\alpha$ ). Finally, $\mathrm{Al}_{8} \mathrm{FeMg}_{3} \mathrm{Si}_{6}$ and $\mathrm{Mg}_{2} \mathrm{Si}$ are formed, marking the end of solidification. In the fully solid state, $\mathrm{Al}_{5} \mathrm{Cu}_{2} \mathrm{Mg}$ and $\mathrm{MgZn}_{2}$ are also expected to form in the alloy.

Figure 2 shows the fraction liquid and its corresponding sensitivity, (f $f_{1}$ s. T (black) and df/dT vs. T (red)), curves for the Al5Si5Zn0.5Mg alloy under the non-equilibrium Scheil condition. The phase transformations during solidification under the Scheil condition are the same as those predicted for equilibrium: Al- $\alpha$ phase is formed at $616^{\circ} \mathrm{C}$ (liquidus), followed by AlFeSi- $\beta$ phase at $564{ }^{\circ} \mathrm{C}$ and $\mathrm{f}_{1}=0.42$ and Si-rich eutectic at $561^{\circ} \mathrm{C}$ and $\mathrm{f}_{1}=0.40$, corresponding to the eutectic knee in the $\mathrm{f}_{1} \mathrm{vs}$. T curve. Finally, $\mathrm{Al}_{8} \mathrm{FeMg}_{3} \mathrm{Si}_{6}$ phase is formed at $544{ }^{\circ} \mathrm{C}$ and $\mathrm{f}_{1}=0.12$, and $\mathrm{Mg}_{2} \mathrm{Si}$ is formed at $537.5^{\circ} \mathrm{C}$ and $\mathrm{f}_{1}=0.09$, followed by the end of solidification at $490{ }^{\circ} \mathrm{C}$ (solidus).

SSM processing must be performed (a) in the temperature range above the eutectic knee to avoid the formation of a eutectic microstructure or needle-like particles that would adversely affect the thixotropic behavior of the semisolid slurry and (b) in a region with low sensitivity $\left(\mathrm{df}_{1} / \mathrm{dT}<0.03{ }^{\circ} \mathrm{C}\right)^{15}$ to allow adequate control and repeatability of the process. Above the eutectic knee in Figure 2 all the sensitivity values

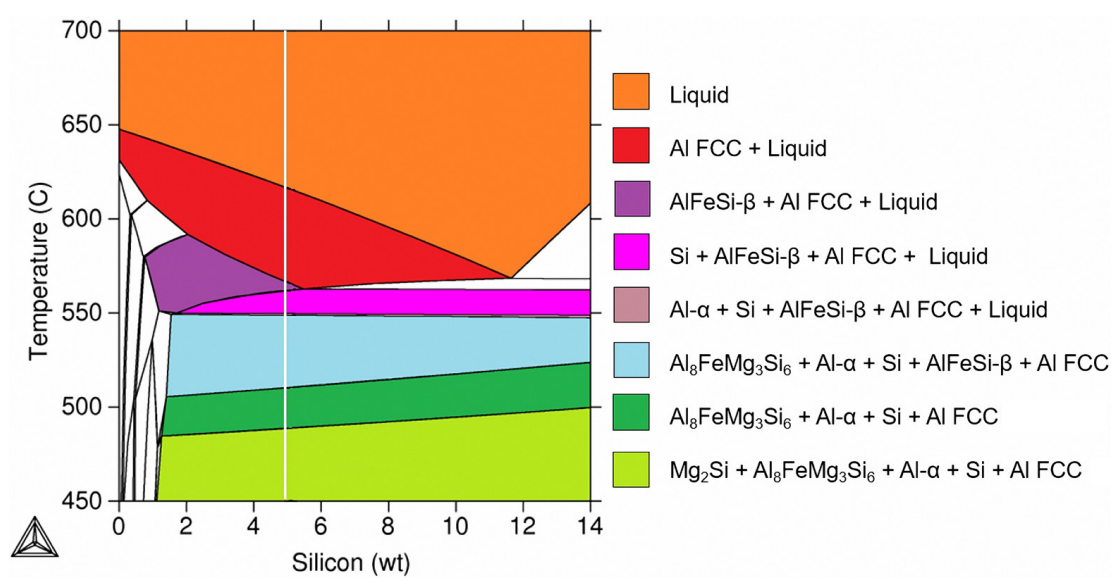

Figure 1. Phase diagram at thermodynamic equilibrium for the Al5Si5Zn0.5Mg alloy. The vertical line (white) corresponds to the $\mathrm{Si}$ content in the alloy studied ( $5 \mathrm{wt} . \%)$. Colored phase fields are described on the right of the diagram. 


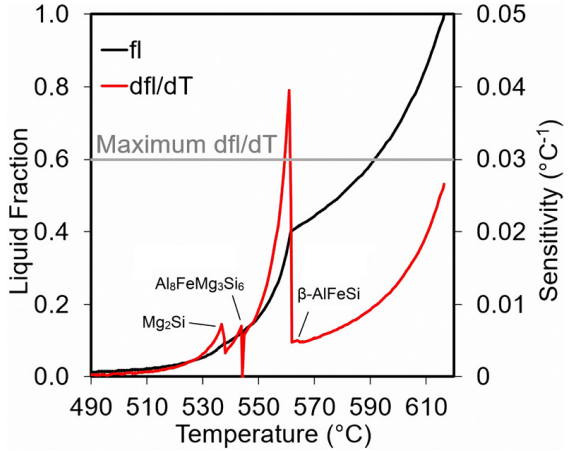

Figure 2. Fraction liquid, $\mathrm{f}_{1}$ vs. T (black) and sensitivity, df/dT vs. T (red), curves for the A15Si5Zn $0.5 \mathrm{Mg}$ alloy under the non-equilibrium Scheil condition. The upper limit for sensitivity above the eutectic knee is indicated in gray.
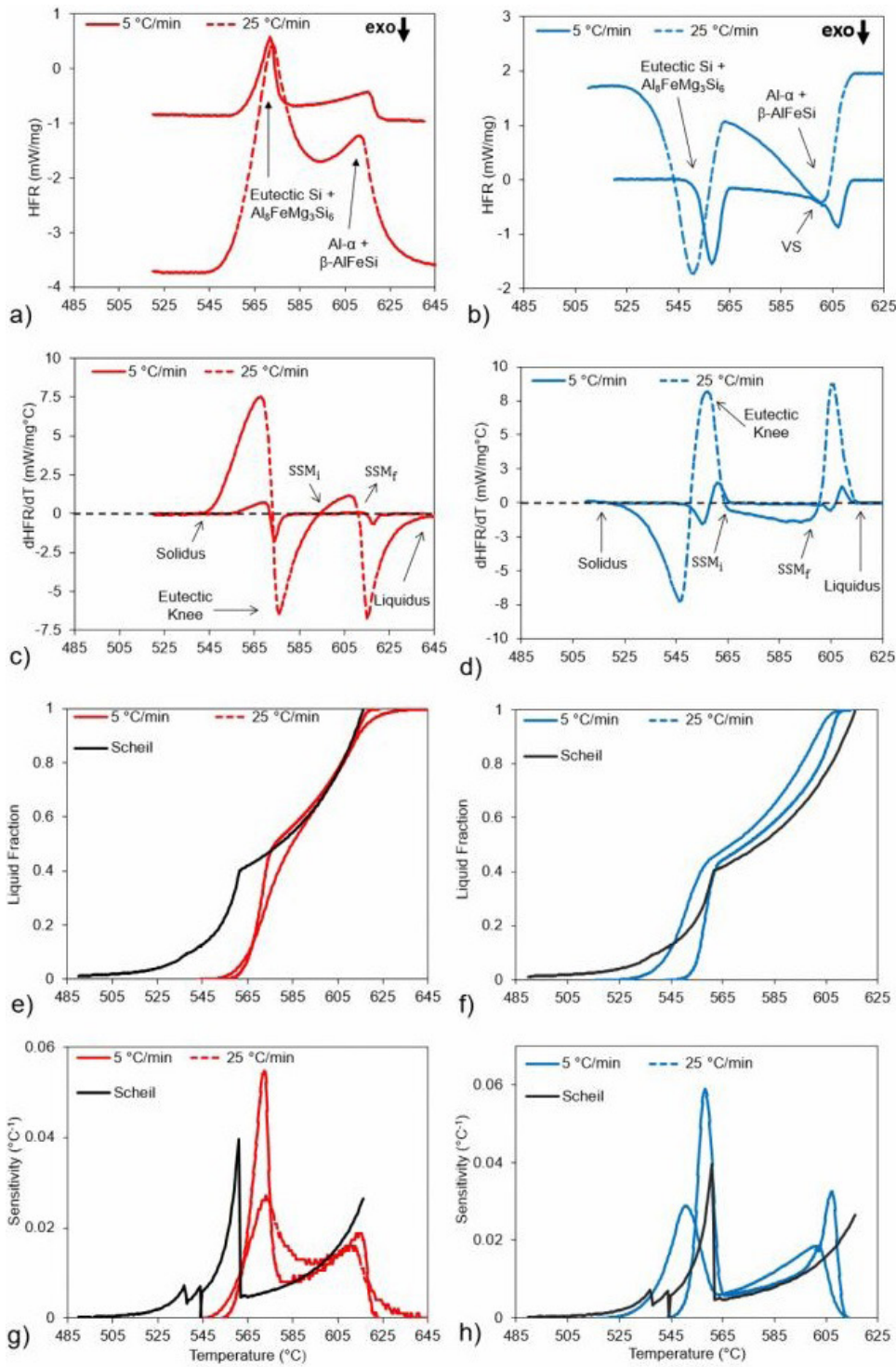

Figure 3. HFR ( $a, b), d H F R / d T ~(c, d), f_{1}(e, f)$ and df $/ d T(g, h)$ vs. T curves for the Al5Si5Zn0.5Mg alloy for heating (left, red) and cooling (right, blue) cycles performed at $5{ }^{\circ} \mathrm{C} / \mathrm{min}$ (continuous line) and $25^{\circ} \mathrm{C} / \mathrm{min}$ (dashed line). The values predicted by numerical simulation under the Scheil condition are shown for reference (black curves). Phase transformations and temperatures of interest for SSM processing are highlighted. The VS arrow indicates "visible superposition" of phase transformations in the DSC curve. 
temperature) and another probably corresponding to melting of the Si-rich eutectic phase and tertiary $\mathrm{Al}_{8} \mathrm{FeMg}_{3} \mathrm{Si}_{6}$ (the peak at a lower temperature). The DSC cooling cycles (Figure $3 \mathrm{~b}$ ) show similar behavior, with two exothermic valleys associated with the same phase transformations discussed above, but which now occur under solidification conditions.

The hypothesis of multiple phases melting/solidifying at a single peak/valley in Figs. $3 \mathrm{a} / \mathrm{b}$ is justified, as in previous papers $^{25,26,34}$, by the proximity of the temperature ranges predicted by the Scheil condition for the phase transformations considered here: the Al- $\alpha+\mathrm{Al}-\mathrm{Fe}-\mathrm{Si}-\beta$ phases range from 561 to $616^{\circ} \mathrm{C}$ on the Scheil curve, while on the experimental curve nearest the simulation condition, i.e., solidification at $5{ }^{\circ} \mathrm{C} / \mathrm{min}$ (Figure $3 \mathrm{~b}$, continuous line), the valley associated with these transformations occurs from 561 to $614{ }^{\circ} \mathrm{C}$. Likewise, the $\mathrm{Si}$-eutectic $+\mathrm{Al}_{8} \mathrm{FeMg}_{3} \mathrm{Si}_{6}$ phases range from 544 to $561{ }^{\circ} \mathrm{C}$ in the Scheil simulation and their associated valley in the DSC curve ranges from 542 to $561{ }^{\circ} \mathrm{C}$. The superposition in the Al- $\alpha+\mathrm{Al}-\mathrm{Fe}-\mathrm{Si}-\beta$ valley is not only supported by the Scheil prediction but also clearly visible in the DSC cooling curve at $5^{\circ} \mathrm{C} / \mathrm{min}$ in the form of a wave on the left of this valley indicated by an arrow (VS, visible superposition) in Figure $3 b$.

The DSC derivative curves (Fig. 3c/d) are used in the DM to identify the temperatures of interest in the thixoformability analysis of the A15Si5Zn0.5Mg alloy: the solidus, liquidus, working window $\left(T_{S S M I}\right.$ and $\left.T_{S S M F}\right)$ and eutectic knee for thixoforming/rheocasting. These temperatures are indicated by arrows in Fig. 3c/d and are shown in Table 2.

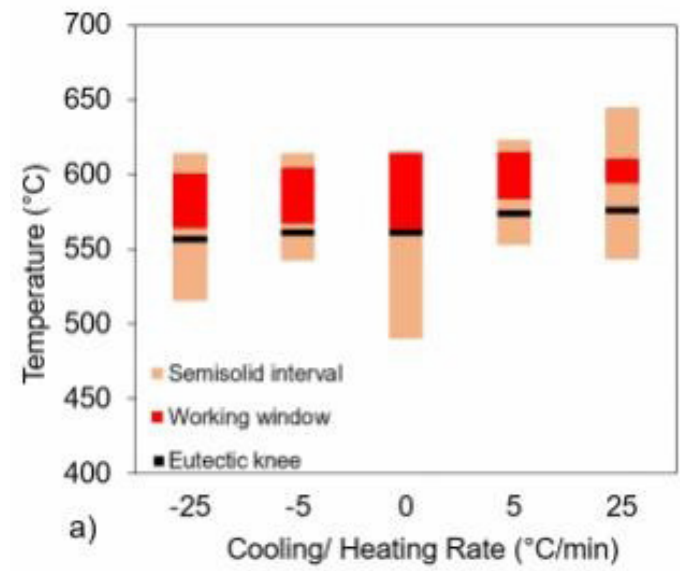

The faster the heating/cooling rate, the softer the knee corresponding to the eutectic transformation in the $\mathrm{f}_{1} \mathrm{vs}$. $\mathrm{T}$ curves (Fig. 3e/f). This smoothing is a result of the delay in the phase transformations and the increase in the temperature range in which these occur as the distance from the equilibrium conditions increases ${ }^{25,26,34}$.

The sensitivity curves (Fig. $3 \mathrm{~g} / \mathrm{h}$ ) also tend to become less pronounced as the heating/cooling rate increases. The peaks in the curves decrease and extend over a wider temperature range as the distance from equilibrium increases. This graphical behavior is inherited from the original $f_{l} v s$. $T$ curves. The Scheil curves for $\mathrm{f}_{1}$ vs. T (Fig. 3e/f) and df/dT vs. T (Fig. $3 \mathrm{~g} / \mathrm{h}$ ) correspond well to the cooling curves, which is expected as the simulation was performed considering solidification.

The respective liquid fractions $\left(f_{1 \text { Knee }}, f_{1 \text { SSMI }}\right.$ and $f_{1 \text { SSMF }}$ ) were identified on the $f_{1}$ vs. $T$ curves (Fig. $3 \mathrm{e} / \mathrm{f}$ ) using the temperatures of the eutectic knee and thixoforming interval obtained by the DM (Fig. 3c/d). To establish an adequate working window, the maximum sensitivity $\left(\mathrm{df}_{1} / \mathrm{dT}_{\max }\right)$ in the proposed interval (between $\mathrm{T}_{\text {SSMI }}$ and $\mathrm{T}_{\text {SSMF }}$ ) was determined from the sensitivity graphs (Fig. $3 \mathrm{~g} / \mathrm{h}$ ). This information was then used to assess the thermodynamic stability and determine whether the $0.03{ }^{\circ} \mathrm{C}^{-1}$ criterion was met. The resulting data are shown in Table 2 and were used to plot the semisolid range, working window and knee for the A15Si5Zn0.5Mg alloy in terms of temperature (Figure 4a) and liquid fraction (Figure $4 \mathrm{~b}$ ). The values predicted by numerical simulation (Scheil) are shown for reference as a heating rate $=0$. Cooling rates are represented as negative heating rates.

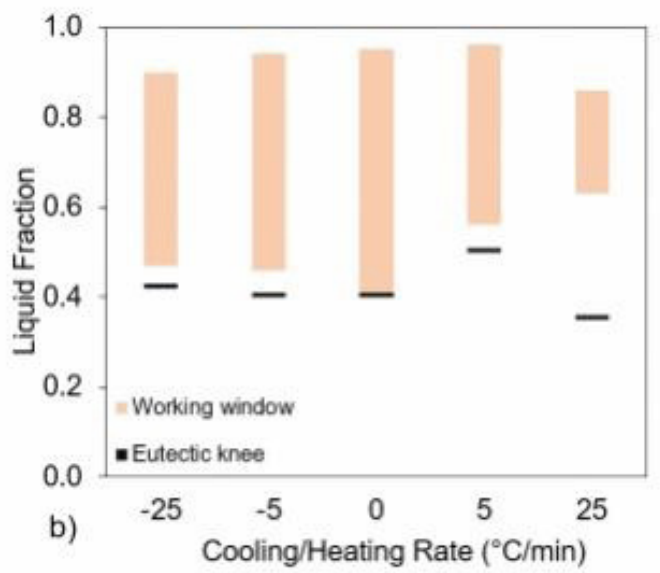

Figure 4. Key thixoforming parameters for $\mathrm{A} 15 \mathrm{Si} 5 \mathrm{Zn} 0.5 \mathrm{Mg}$ alloy under different kinetic conditions: temperature (a) and liquid fraction (b). Cooling rates are represented by negative heating rates, and the Scheil condition is shown as a heating rate $=0$.

Table 2. Key thixoforming parameters for $\mathrm{A} 15 \mathrm{Si} 5 \mathrm{Zn} 0.5 \mathrm{Mg}$ alloy under different kinetic conditions. Cooling rates are represented as negative heating rates, and the Scheil condition is shown as a heating rate $=0$.

\begin{tabular}{|c|c|c|c|c|c|c|c|c|c|c|c|c|}
\hline $\begin{array}{l}\text { Heating rate } \\
\left({ }^{\circ} \mathrm{C} / \mathrm{min}\right)\end{array}$ & $\begin{array}{l}\mathrm{T}_{\text {solidus }} \\
\left({ }^{\circ} \mathrm{C}\right)\end{array}$ & $\begin{array}{l}\mathrm{T}_{\text {Knee }} \\
\left({ }^{\circ} \mathrm{C}\right)\end{array}$ & $\begin{array}{l}\mathrm{T}_{\text {SSMI }} \\
\left({ }^{\circ} \mathrm{C}\right)\end{array}$ & $\begin{array}{l}\mathrm{T}_{\text {SSMF }} \\
\left({ }^{\circ} \mathrm{C}\right)\end{array}$ & $\begin{array}{c}\mathrm{T}_{\text {liquidus }} \\
\left({ }^{\circ} \mathrm{C}\right)\end{array}$ & $\begin{array}{l}\Delta \mathrm{T}_{\mathrm{sl}} \\
\left({ }^{\circ} \mathrm{C}\right)\end{array}$ & $\begin{array}{c}\Delta \mathrm{T}_{\text {SSM }} \\
\left({ }^{\circ} \mathrm{C}\right)\end{array}$ & $\mathrm{f}_{1 \text { Knee }}$ & $\mathrm{f}_{1 \text { SSMI }}$ & $\mathrm{f}_{1 \text { SSMF }}$ & $\Delta \mathrm{f}_{1 \mathrm{SSM}}$ & $\begin{array}{c}\mathrm{df}_{1} / \mathrm{dT}_{\text {max }} \\
\left({ }^{\circ} \mathrm{C}^{-1}\right)\end{array}$ \\
\hline-25 & 515 & 557 & 564 & 601 & 614 & 99 & 37 & 0.42 & 0.47 & 0.90 & 0.43 & 0.018 \\
\hline-5 & 542 & 561 & 567 & $605^{*}$ & 614 & 72 & 38 & 0.40 & 0.46 & 0.85 & 0.39 & 0.029 \\
\hline 0 & 490 & 561 & 564 & 614 & 616 & 126 & 50 & 0.40 & 0.42 & 0.96 & 0.54 & 0.024 \\
\hline 5 & 552 & 574 & 584 & 615 & 623 & 71 & 31 & 0.45 & 0.56 & 0.96 & 0.40 & 0.020 \\
\hline 25 & 543 & 576 & 594 & 611 & 644 & 101 & 17 & 0.35 & 0.63 & 0.86 & 0.23 & 0.015 \\
\hline
\end{tabular}

$* \mathrm{~T}_{\mathrm{SSMF}}$ value corrected to achieve a maximum sensitivity of $0.029^{\circ} \mathrm{C}^{-1}$ in the working window. 
The following remarks can be made in relation to the thermodynamic phase transition presented in Figure 4 and Table 2:

a) Semisolid interval - The data presented here show that the cooling rate changes little the liquidus temperature, since the temperature predicted by TC Scheil is $616^{\circ} \mathrm{C}$ and for cooling rates of -5 and $-25^{\circ} \mathrm{C} / \mathrm{min}$ the $\mathrm{T}_{\text {liquidus }}$ decreases to $615^{\circ} \mathrm{C}$, however for the heating rate, +5 and $+25^{\circ} \mathrm{C} / \mathrm{min}$, it have a more significant changing the $\mathrm{T}_{\text {liquidus, }}$ to 623 and 644 ${ }^{\circ} \mathrm{C}$ respectively. In other words, $\mathrm{T}_{\text {liquidus }}$ suffers delay only for heating, due to the reaction inertia. For the solidus temperature TC Scheil predicts a very low temperature, around $490^{\circ} \mathrm{C}$; for the DSC data, at cooling rates of -5 and $-25^{\circ} \mathrm{C} / \mathrm{min}$ the $\mathrm{T}_{\text {solidus }}$ is 542 and $515^{\circ} \mathrm{C}$, that is, the higher the cooling rate, lowest $\mathrm{T}_{\text {solidus }}$, also due to inertia, although the same phenomenon occurs for heating. For heating rates of +5 and $+25^{\circ} \mathrm{C} / \mathrm{min}$ one have $\mathrm{T}_{\text {solidus }}$ of 552 and $543{ }^{\circ} \mathrm{C}$ respectively. In this case, the acceleration is given by the facilitation of the dissolution and melting of the intermetallic phases present due to the greater amount of energy as a function of time. Therefore, there is a $30^{\circ} \mathrm{C}$ increase in the semisolid interval as the heating rate increases: at $5^{\circ} \mathrm{C} / \mathrm{min}, \Delta \mathrm{T}_{\mathrm{s}-1}=71{ }^{\circ} \mathrm{C}$ and at $25^{\circ} \mathrm{C} / \mathrm{min}, \Delta \mathrm{T}_{\mathrm{s}-1}=101{ }^{\circ} \mathrm{C}$. For the cooling curves, an increase of $27^{\circ} \mathrm{C}$ in the semisolid interval is observed: at $-5^{\circ} \mathrm{C} / \mathrm{min}, \Delta \mathrm{T}_{\mathrm{s}-1}=72{ }^{\circ} \mathrm{C}$ and at $-25^{\circ} \mathrm{C} / \mathrm{min}, \Delta \mathrm{T}_{\mathrm{s}-1}=99^{\circ} \mathrm{C}$. This trend is a result of the delaying and extending of the melting/solidification reaction as kinetic effects become stronger. Furthermore, higher heating/cooling rates result in a larger driving force (less superheating/supercooling) for melting/solidification, making the reaction start sooner, i.e., faster heating/cooling curves have lower solidus/higher liquidus points than slower ones, resulting in larger semisolid intervals ${ }^{25}$. Particularly for cooling cycles, the liquidus is pushed to higher temperatures because heterogeneous nucleation of the solid embryos is facilitated as a result of contact with the DSC crucible, oxides on the melt surface or fine particles dispersed throughout the liquid, an effect not considered in the CALPHAD simulation that also results in less supercooling being needed to start solidification ${ }^{33}$.

The main factor responsible for enlargement of the semisolid interval for heating curves is the increase in the liquidus temperature $\left(\Delta \mathrm{T}_{\text {liquidus }}=21^{\circ} \mathrm{C}\right.$ between heating rates of 5 and $25^{\circ} \mathrm{C} / \mathrm{min}$ ), followed by the smaller decrease in the solidus temperature $\left(\Delta \mathrm{T}_{\text {solidus }}=-9{ }^{\circ} \mathrm{C}\right.$ between heating rates of 5 and $25^{\circ} \mathrm{C} / \mathrm{min}$ ). Likewise, for cooling curves the factor responsible for enlargement of the semisolid interval is the decrease in the solidus temperature $\left(\Delta \mathrm{T}_{\text {solidus }}=-27^{\circ} \mathrm{C}\right.$ between cooling rates of -5 and $-25^{\circ} \mathrm{C} / \mathrm{min}$ ). For these cycles, an insignificant change in the liquidus temperature was observed $\left(\Delta \mathrm{T}_{\text {liquidus }}=0.04{ }^{\circ} \mathrm{C}\right.$ between -5 and $\left.-25^{\circ} \mathrm{C} / \mathrm{min}\right)$. This result shows that the delaying effect of the melting/ cooling reaction (resulting in a higher liquidus/lower solidus) plays a greater role in enlarging the semisolid range than the larger driving force (lower solidus/higher liquidus) observed with the rise in the heating/cooling rate. The values for liquid fraction as a function of temperature obtained by numerical simulation under the Scheill condition are similar to those obtained experimentally by DSC when the cooling curves are analyzed, especially the curve for the lower cooling rate, $5^{\circ} \mathrm{C} / \mathrm{min}$. b) Eutectic knee - Despite the changes in the shape of the curves caused by kinetic effects, the temperature corresponding to the knee remains almost unaltered with the increase in heating/cooling rate. For the heating cycles, $\Delta \mathrm{T}_{\text {knee }}=2{ }^{\circ} \mathrm{C}$ and for the cooling cycles, $\Delta \mathrm{T}_{\text {knee }}=4{ }^{\circ} \mathrm{C}$ under the conditions analyzed.

However, because of the delayed/extended melting reaction and smoothing of the knee, the $\mathrm{f}_{1} \mathrm{vs}$. T curves around the knee (Fig. 3e/f) move toward progressively higher/lower temperatures (right/left) as the heating/cooling rate increases. This effect causes the knee liquid fraction to decrease by 0.10 as the heating rate increases from $5^{\circ} \mathrm{C} / \mathrm{min}\left(f_{l \text { Knee }}=0.45\right)$ to $25^{\circ} \mathrm{C} / \mathrm{min}\left(f_{l \text { Knee }}=0.35\right)$. For cooling, the knee liquid fraction increases slightly (by 0.02) as the cooling rate increases from $-5^{\circ} \mathrm{C} / \mathrm{min}\left(f_{l \text { Knee }}=0.40\right)$ to $-25^{\circ} \mathrm{C} / \mathrm{min}\left(f_{l \text { Knee }}=0.42\right)$. The knee temperature and liquid fraction for the Scheil curve are similar to those for the cooling curve nearer equilibrium, i.e., $-5^{\circ} \mathrm{C} / \mathrm{min}$, which is in agreement with the thermodynamic conditions considered in the simulation.

c) SSM working window - For the cycles at 5, 25 and $-25^{\circ} \mathrm{C} / \mathrm{min}$, the sensitivity values in Table 2 are below the 0.03 ${ }^{\circ} \mathrm{C}^{-1}$ limit, so the original SSM working window suggested by the DM was maintained. However, for the cycle at -5 ${ }^{\circ} \mathrm{C} / \mathrm{min}$, the original value of $\mathrm{T}_{\mathrm{SSMF}}=507^{\circ} \mathrm{C}$ was changed to $505{ }^{\circ} \mathrm{C}$ to reduce the sensitivity from 0.032 to $0.029^{\circ} \mathrm{C}^{-1}$ (Table 2 and Figure 4 already contain the corrected value for this parameter).

The thixoforming interval (heating) for the A15Si $5 \mathrm{Zn} 0.5 \mathrm{Mg}$ alloy becomes smaller as the heating rate increases, decreasing by $14^{\circ} \mathrm{C}\left(31^{\circ} \mathrm{C}\right.$ to $\left.17^{\circ} \mathrm{C}\right)$ between the lowest and highest heating rates. Similarly, the liquid fraction interval decreases by 0.17 between heating rates of $5^{\circ} \mathrm{C} / \mathrm{min}\left(\Delta f_{l \mathrm{SSM}}=0.40\right)$ and $25^{\circ} \mathrm{C} / \mathrm{min}\left(\Delta f_{\text {l SSM }}=0.23\right)$. The main factor responsible for this narrowing of the thixoforming working window is the increase in the lower limit $\left(\Delta \mathrm{T}_{\text {SSMI }}=10^{\circ} \mathrm{C}\right.$ and $\Delta f_{l \text { SSMI }}=0.07$ between heating rates of 5 and $25{ }^{\circ} \mathrm{C} / \mathrm{min}$ ) followed by a smaller decrease in the upper limit $\left(\Delta \mathrm{T}_{\mathrm{SSMF}}=-4{ }^{\circ} \mathrm{C}\right.$ and $\Delta f_{l \mathrm{SSMF}}=-0.10$ between heating rates of 5 and $\left.25^{\circ} \mathrm{C} / \mathrm{min}\right)$.

The rheocasting interval (cooling) remains practically unaltered as the cooling rate increases, decreasing by only $1{ }^{\circ} \mathrm{C}\left(38^{\circ} \mathrm{C}\right.$ to $\left.37^{\circ} \mathrm{C}\right)$ between the lowest and highest cooling rates. The liquid fraction interval increases slightly (by 0.04 ) with the increase in cooling rate: from $\Delta f_{l \text { ssm }}=0.39$ at $5{ }^{\circ} \mathrm{C} / \mathrm{min}$ to 0.43 at $25^{\circ} \mathrm{C} / \mathrm{min}$. Two factors are responsible for this practically unaltered rheocasting working window: (a) the decrease in both the lower and upper limit with the increase in cooling rate due to the delay caused by kinetic effects and (b) the fact that the decrease in both limits are practically the same: $\Delta \mathrm{T}_{\text {SSMI }}=-3{ }^{\circ} \mathrm{C}$ and $\Delta \mathrm{T}_{\text {SSMI }}=-4{ }^{\circ} \mathrm{C}$.

Therefore, both techniques help to correctly identify the optimal temperature range to be used in semisolid processing. That is, the simulation via Thermo-Cal ${ }^{\mathbb{B}}$ gives us the characteristics and phases that will possibly be present at a certain temperature, and the DSC gives us the interval where the processing is likely to be more successful, avoiding the unstable eutectic transformation and also indicating a temperature target where the solid fraction is ideal to increase the viscosity of the mush material (between 35 and 55\%), and where the processing is easily controllable, that is, where the sensitivity is low $\left(<0.03{ }^{\circ} \mathrm{C}^{-1}\right)^{3,16,25}$. 


\subsection{As-cast alloy}

The microstructure of the as-cast $\mathrm{A} 15 \mathrm{Si} 5 \mathrm{Zn} 0.5 \mathrm{Mg}$ alloy is shown in Figure 5 as a reference for the heat-treated conditions. Figure $5 \mathrm{a}$ shows grains, and Figure $5 \mathrm{~b}$ globules, that is, in fact, a fragmented dendrite structure. The microstructure is essentially formed by a dendritic Al-rich primary phase and intergranular Si-rich main eutectic. The average values \pm standard errors of the microstructural parameters for the as-cast condition are: $\mathrm{G}_{\mathrm{S}}=152 \pm 6 \mu \mathrm{m}$; dendritic arm spacing (the reference parameter for $\mathrm{GL}_{\mathrm{S}}$ after heating) $=25 \pm 3 \mu \mathrm{m}$.

Other tertiary elements in the alloy could be present as a solid solution in the $\mathrm{Al}_{\alpha}$ matrix (mainly $\mathrm{Zn}$ ) or segregated in the eutectic, forming intermetallic phases at the interdendritic space (such as $\mathrm{Si}, \mathrm{Mg}, \mathrm{Fe}, \mathrm{Mn}$ and $\mathrm{Cu}$ ) but those phases were not observable at optical microscopy. Although some of these phases are highlighted in Figure 5c: dark grey $\mathrm{Si}$ crystals, light grey $\mathrm{Al}_{5} \mathrm{FeSi}-\beta$ needle-like particles and light grey larger particles of $\alpha-\mathrm{Fe}\left[\mathrm{Al}_{15}(\mathrm{FeMn})_{3} \mathrm{Si}_{2}\right]^{24,34-43}$, all identifiable by comparison.

\subsection{Partial melting}

Figure 6 shows the microstructure (grains - color micrographs; globules - B\&W micrographs) of samples heat treated isothermally at $594{ }^{\circ} \mathrm{C}$ for $0 \mathrm{~s}(\mathrm{a}, \mathrm{b}), 30 \mathrm{~s}(\mathrm{~d}, \mathrm{e})$, $60 \mathrm{~s}(\mathrm{~g}, \mathrm{~h})$ and $90 \mathrm{~s}(\mathrm{j}, \mathrm{k})$ and the corresponding thixoformed disks $(\mathrm{c}, \mathrm{f}, \mathrm{i}, \mathrm{l})$. Table 3 shows the average values of the microstructural parameters for these conditions.

The colored micrographs (Figure 6 - left) show a significant number of $\mathrm{Al}-\alpha$ phase particles with similar colors close to each other, indicating a high level of threedimensional connectivity between the globules. For 0 to $30 \mathrm{~s}$ (Figure 6a and d), a coarse dendrite-like morphology inherited from the original cast microstructure (Figure 5) is still evident. As the soak time increases from 30 to $90 \mathrm{~s}$ (Fig. $6 \mathrm{~g}$ and j), a visible reduction in $\mathrm{G}_{\mathrm{S}}$ is observed. Grain refinement occurs because of the breakdown of the dendritic arms following dissolution of thinner particles caused by

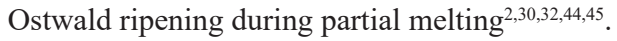

As observed for the grain analysis, the conventional B\&W micrographs (Figure 6 - middle) show progressive, discrete refinement and spheroidization of the Al- $\alpha$ phase globules with increasing soak time. Spheroidization can also be observed from the circularity measurements in Table 3 and is due to the tendency for the surface-area-to-volume ratio of the particles to decrease as a result of atomic diffusion during coarsening. Particle refinement is a consequence of the same phenomenon discussed for grain size.

The ratio $\mathrm{G}_{\mathrm{s}} / \mathrm{GL}_{\mathrm{s}}$ (Table 3) gives an indication of the degree of connection between $\alpha$-phase globules, i.e., the complexity of the three-dimensional dendritic "skeleton". The decrease in this parameter with increasing soak time from 0 to $90 \mathrm{~s}$ is due to grain fragmentation as well as refinement, which makes the dimensions of the grains increasingly similar to those of the globules $\left(\mathrm{G}_{\mathrm{s}} / \mathrm{GL}_{\mathrm{S}} \rightarrow 1\right)^{30,32}$

Because of the trends discussed above, there is a visible change in the appearance of the thixoformed disks as the holding time increases from 0 to $90 \mathrm{~s}$ (Figure $6 \mathrm{c}, \mathrm{f}, \mathrm{i}$ and 1). As the grains and globules became increasingly refined and round (fewer dendritic connections), the consequent smoother flow of the semisolid slurry led to disks with softer edges and a rounder geometry.

Neighboring globules become increasingly interconnected as soak time increases. This is expected since the distance between groups of neighboring particles decreases progressively and in some cases even becomes zero as a direct consequence of coarsening. Interconnected particles are particularly visible for the $90 \mathrm{~s}$ soak time, as highlighted in Figure 7a (white circles). Interconnectivity between the solid particles is undesirable because it contributes to the
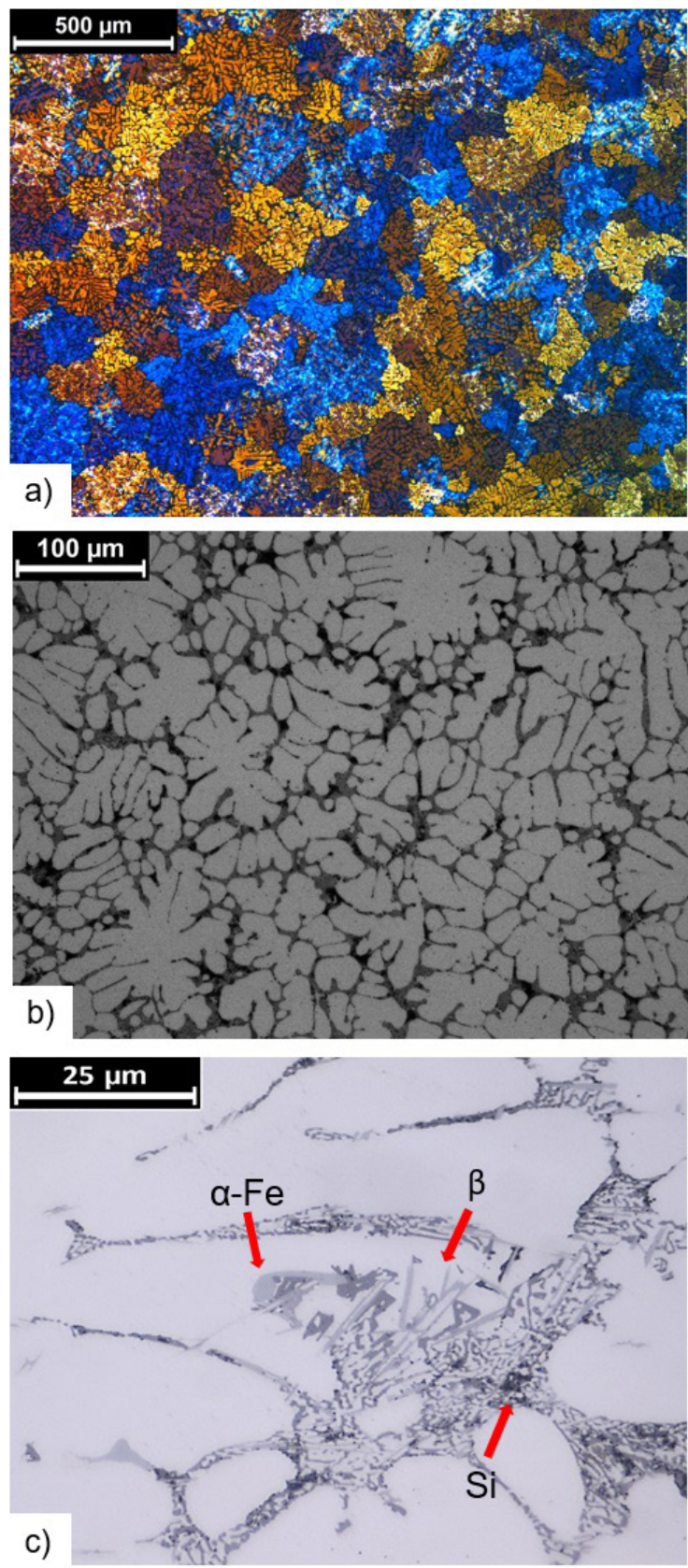

Figure 5. Micrographs of the as-cast Al5Si5Zn0.5Mg alloy. (a) Polarized light optical micrograph highlighting grains; (b) conventional B\&W optical micrograph highlighting globules; and (c) conventional $\mathrm{B} \& \mathrm{~W}$ optical micrograph highlighting eutectic phases. 
formation of a cohesive network that hampers the flow of the semisolid metal ${ }^{32,45}$

The formation of large agglomerates along with smaller particles in the microstructure as a result of Ostwald ripening promotes thickening of the liquid film and segregation of the liquid, leading to regions with liquid "pockets" 45,46 , as clearly seen for a holding time of $90 \mathrm{~s}$ and highlighted in Figure 7a (arrows). Furthermore, the long exposure in the semisolid state causes liquid to segregate towards the upper portion of the partially melted sample because of the lower density
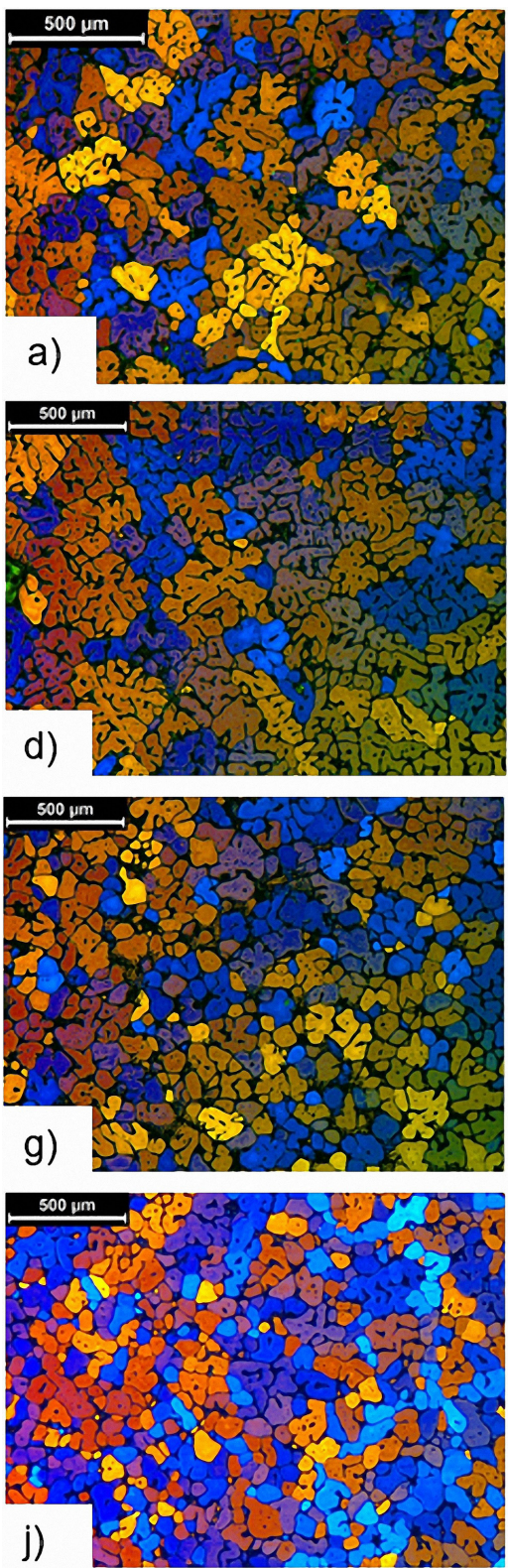
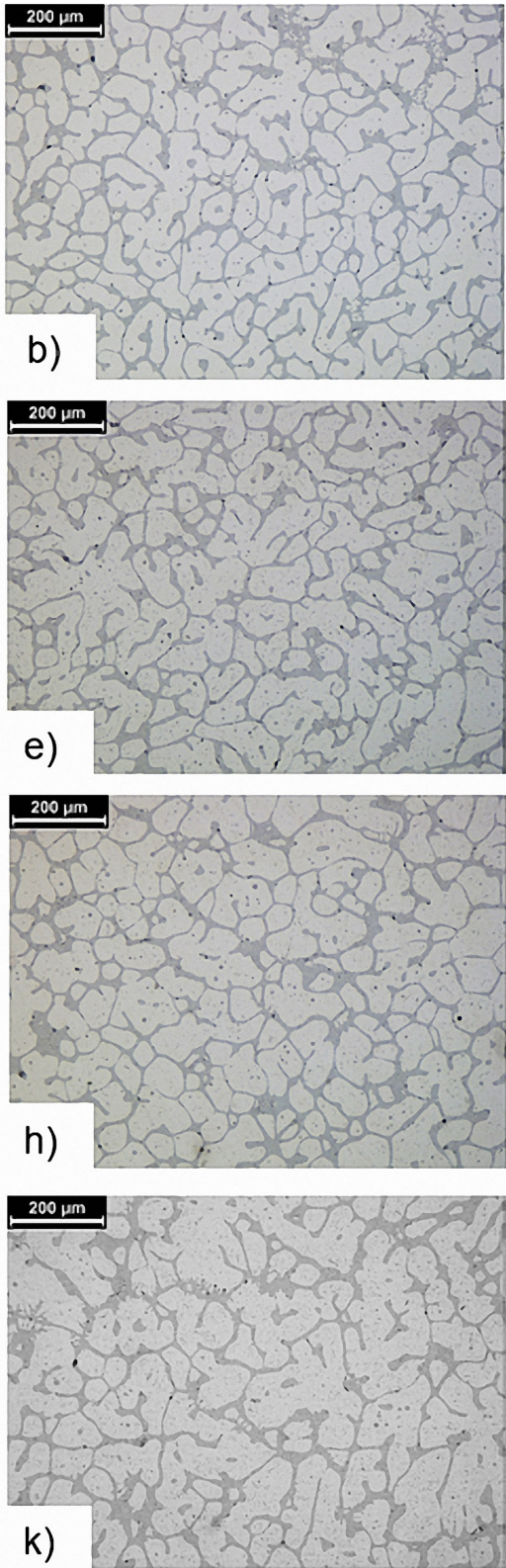
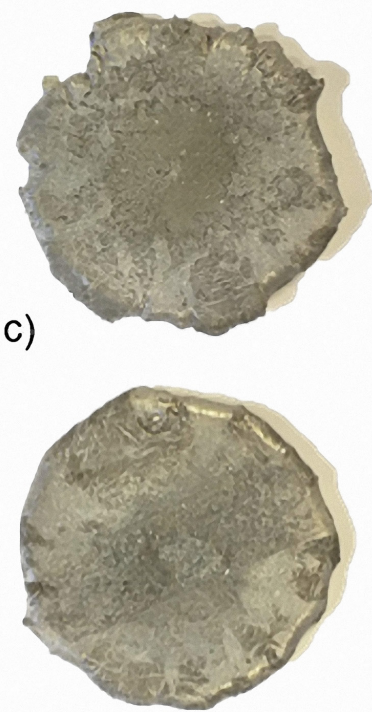

f)

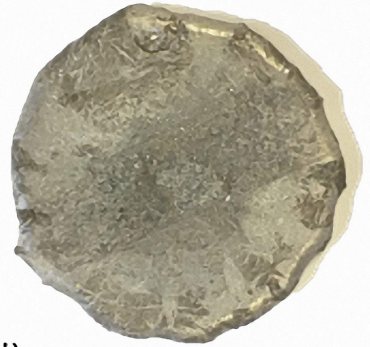

i)

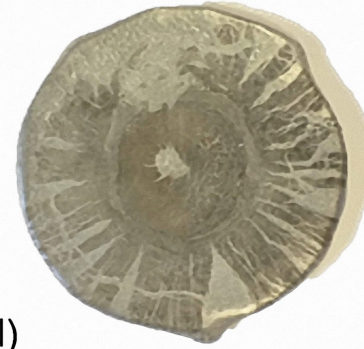

Figure 6. Micrographs of the partially melted Al5Si5Zn0.5Mg alloy (grains - color; globules $-\mathrm{B} \& \mathrm{~W}$ ) heat treated isothermally at $594{ }^{\circ} \mathrm{C}$ for $0 \mathrm{~s}(\mathrm{a}, \mathrm{b}), 30 \mathrm{~s}(\mathrm{~d}, \mathrm{e}), 60 \mathrm{~s}(\mathrm{~g}, \mathrm{~h})$ and $90 \mathrm{~s}(\mathrm{j}, \mathrm{k})$ and the respective thixoformed disks $(\mathrm{c}, \mathrm{f}, \mathrm{i}, \mathrm{l})$.

Table 3. Microstructural parameters of the Al5Si5Zn0.5Mg alloy after partial melting at $594{ }^{\circ} \mathrm{C}$ for four holding times (average \pm standard error).

\begin{tabular}{ccccc}
\hline Holding time $(\mathrm{s})$ & $\mathrm{G}_{\mathrm{S}}(\mu \mathrm{m})$ & $\mathrm{GL}_{\mathrm{s}}(\mu \mathrm{m})$ & $\mathrm{G}_{\mathrm{s}} / \mathrm{GL}_{\mathrm{s}}$ & $\mathrm{C}$ \\
\hline 0 & $188 \pm 10$ & $69 \pm 5$ & $2.7 \pm 1.0$ & $0.51 \pm 0.01$ \\
\hline 30 & $200 \pm 8$ & $81 \pm 2$ & $2.4 \pm 0.6$ & $0.51 \pm 0.01$ \\
\hline 60 & $138 \pm 5$ & $84 \pm 2$ & $1.6 \pm 0.6$ & $0.53 \pm 0.01$ \\
\hline 90 & $108 \pm 3$ & $73 \pm 2$ & $1.5 \pm 0.4$ & $0.59 \pm 0.01$ \\
\hline
\end{tabular}



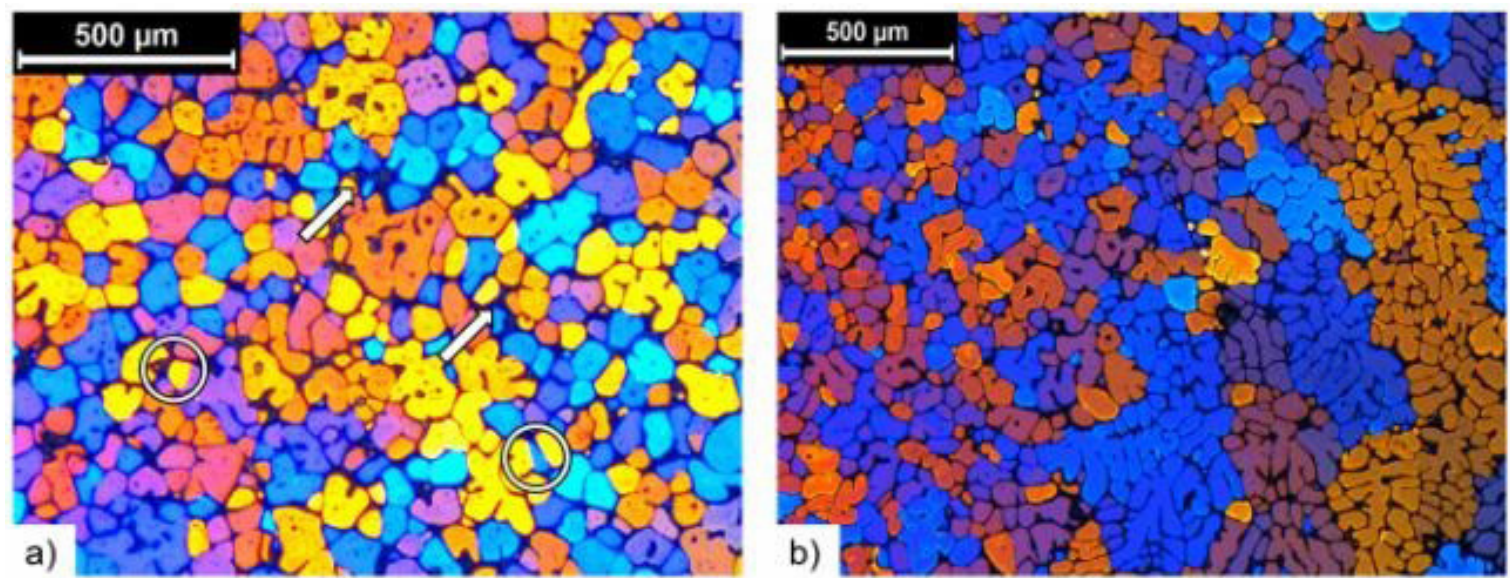

Figure 7. Microstructure of the Al5Si5Zn0.5Mg alloy after $90 \mathrm{~s}$ of heat treatment at $594{ }^{\circ} \mathrm{C}$ : (a) interconnected globules (circles) and liquid pockets (arrows); (b) fine dendrites formed during solidification of liquid-rich region due to segregation.

of liquid compared with solid globules. These segregated regions containing thicker liquid films have enough space to solidify with a fine dendritic morphology, as seen in Figure 7b.

Quantitative analysis of $\mathrm{G}_{\mathrm{s}}$ and $\mathrm{GL}_{\mathrm{s}}$ for the $\mathrm{Al} 15 \mathrm{Si} \mathrm{Zn} 0.5 \mathrm{Mg}$ alloy under the conditions studied suffers from inaccuracy because of the large standard errors of the measurements. Considering (a) the large size of the statistical population used for each parameter ( $n$, given in Section 2) and (b) the high values of the resulting standard errors (obtained using the standard deviation and $n$, as described in Section 2), the variations can be considered to be the result not of inadequate statistical sample sizes but rather of the dispersive nature of the variables analyzed ${ }^{37,40}$. The spread of the measurements can therefore be analyzed in the form of probability distributions for the microstructural parameters $\mathrm{G}_{\mathrm{S}}, \mathrm{GL}_{\mathrm{S}}$ and $\mathrm{C}$, as shown in Figure 8. The average values of $\mathrm{G}_{\mathrm{s}} / \mathrm{GL}_{\mathrm{s}}$ were obtained by an algebraic operation and thus cannot be represented as a statistical distribution.

The maximum frequency of the Gs distribution (Figure 8a) tends to be displaced to lower values as the soak time increases, reflecting the tendency in Table 3. Furthermore, with the increase in soak time, the whole distribution is narrowed towards smaller values, indicating that a longer soak time promotes a more homogeneous, refined microstructure. The distribution of GLs (Figure 8b) also tends to narrow with increasing soak time. However, its maximum frequency remains in the same region (around $70 \mu \mathrm{m}$ ) independently of the soak time. This indicates that while the grain size is reduced by the breakdown of dendritic arms by diffusion, the individual (remaining or broken) arms themselves, i.e., the globules, are, once separated from the original skeleton, much less affected by diffusional mechanisms and their sizes remain centered around a constant value in spite of the increasing soak time. The main effect changing soak time has on these globules over time is to cause a change in roundness.

In general, circularity behaves like a statistical random variable (Figure 8c). There is a discrete transition to a bimodal or even trimodal distribution, indicating the simultaneous
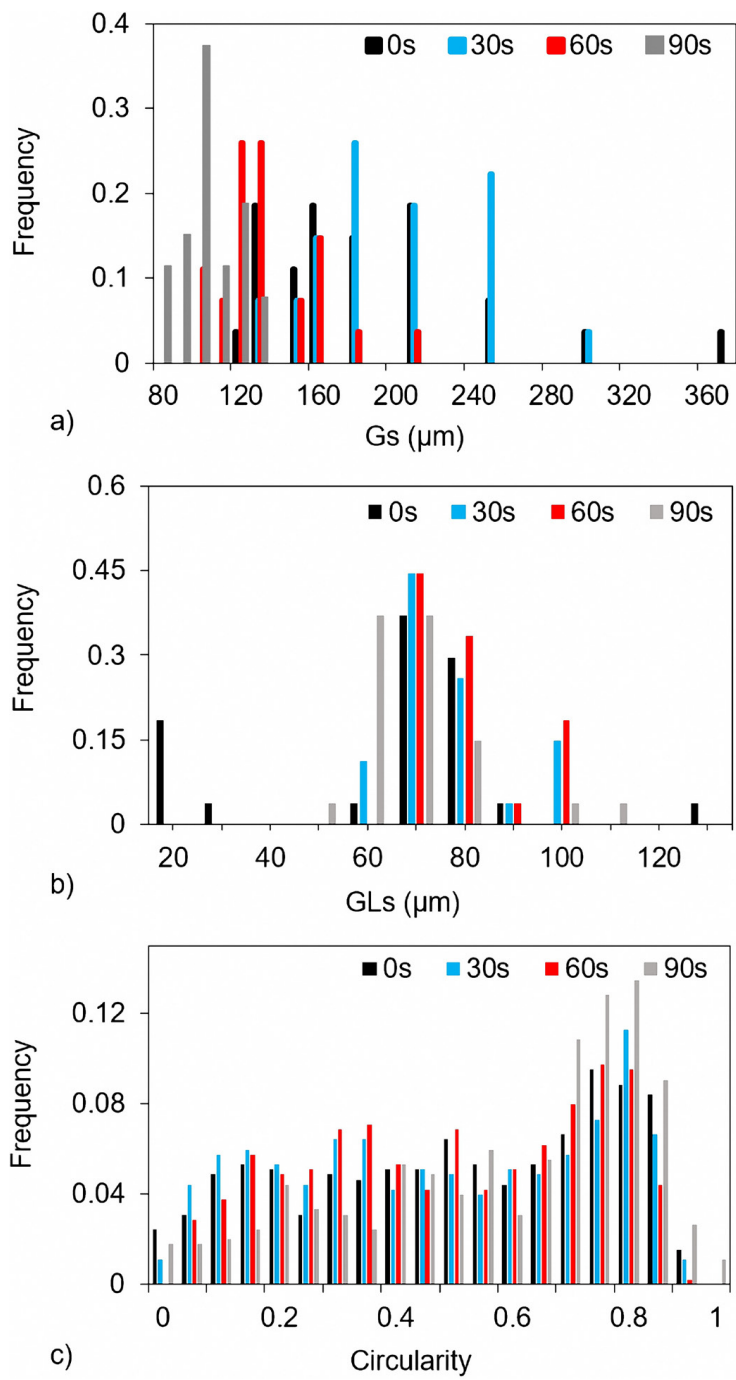

Figure 8. Distribution of $\mathrm{Al} 5 \mathrm{Si} 5 \mathrm{Zn} 0.5 \mathrm{Mg}$ alloy grain size (a), globule size (b) and circularity (c) measured after isothermal heat treatment at $594{ }^{\circ} \mathrm{C}$ for $0,30,60$ and $90 \mathrm{~s}$. 
presence of individual (convex) and interconnected (concave) particles in the microstructure. This in turn is a clear indication of the presence of large agglomerates along with smaller particles because of Ostwald ripening. With the increase in soak time, the maximum frequency of higher circularity values clearly increases (to a maximum of $14 \%$ around $\mathrm{C}=0.83$ for the $90 \mathrm{~s}$ condition), showing that increasing soak time improves spheroidization.

As the present study is only the first stage in the evaluation of the suitability of the Al5Si5Zn0.5Mg alloy, a relatively cheap, conventional casting process was used, resulting in a $G_{S}$ range of $\sim 108$ to $200 \mu \mathrm{m}$. Suitable grain sizes for semisolid slurries produced by conventional casting are usually of the order of $\sim 70$ to $150 \mu \mathrm{m}$ [2,31], i.e., smaller than those observed here. However, a previous work ${ }^{25}$ using an Al-Si-Cu alloy showed that coarse microstructures $\left(\mathrm{G}_{\mathrm{S}}=280 \mu \mathrm{m}\right)$ can provide suitable rheological behavior $\left(\mu_{\max }=1.8 \times 10^{5}\right.$ Pa.s $)$ if the liquid fraction is adjusted to a value at which the globules can move within the liquid even if interconnected to a certain degree.

\subsection{Rheological behavior}

Figure 9 shows the engineering stress vs. engineering strain (a) and apparent viscosity vs. shear rate (b) curves for Al5Si5Zn0.5Mg alloy samples subjected to isothermal heat treatment at $594{ }^{\circ} \mathrm{C}$ for $0,30,60$ and $90 \mathrm{~s}$.

Three regions can be identified in the curves. In the first region, as the compression progresses, the solid dendritic network becomes more interconnected and intricate, leading to an increase in stress and apparent viscosity until a peak is observed in the latter $\left(\mu_{\max }\right)$. In the second region, the dendritic structure can no longer withstand the pressure applied and the dendritic arms break. The progressive movement of particles causes the apparent viscosity to decrease. The stress continues to increase until it reaches a maximum $\left(\sigma_{\max }\right)$ just before the collapse of the dendritic "skeleton". Finally, in the third region, broken particles flow "freely" through the liquid, producing a higher shear rate and a rapid decrease in apparent viscosity, which in turn results in smaller values of stress as the strain continues to increase.

The tests performed here were stopped when a strain of 0.8 was reached for all samples; had the strain been increased further, a fourth region would be seen in the curves, in which the liquid would be fully expelled to the outer radius of the sample, leaving the center of the sample with a high solid fraction. A rapid increase in stress and apparent viscosity would be observed until the end of the test, as if fully solid metal were being formed.

Table 4 shows the rheological parameters of the heattreated samples at the points of maximum apparent viscosity $\left(\mu_{\max }, \dot{\gamma}\right)$ and maximum stress $\left(\sigma_{\max }, \varepsilon\right)$. The rheological data agree with the microstructural results presented here, which indicate that increasing soak time from 0 to $60 \mathrm{~s}$ leads to a reduction in maximum stress and viscosity. However, long soak times at this high temperature cause the remaining solid particles to cluster and aggregate, increasing stress and viscosity. There is therefore an optimal interval for semisolid forming between 30 and 60 s soak time. The values of $\mu_{\text {ma }}$ obtained for the thixoforged A15Si5Zn0.5Mg alloy were of the order of $10^{4} \mathrm{~Pa}$.s. This compares favorably with values
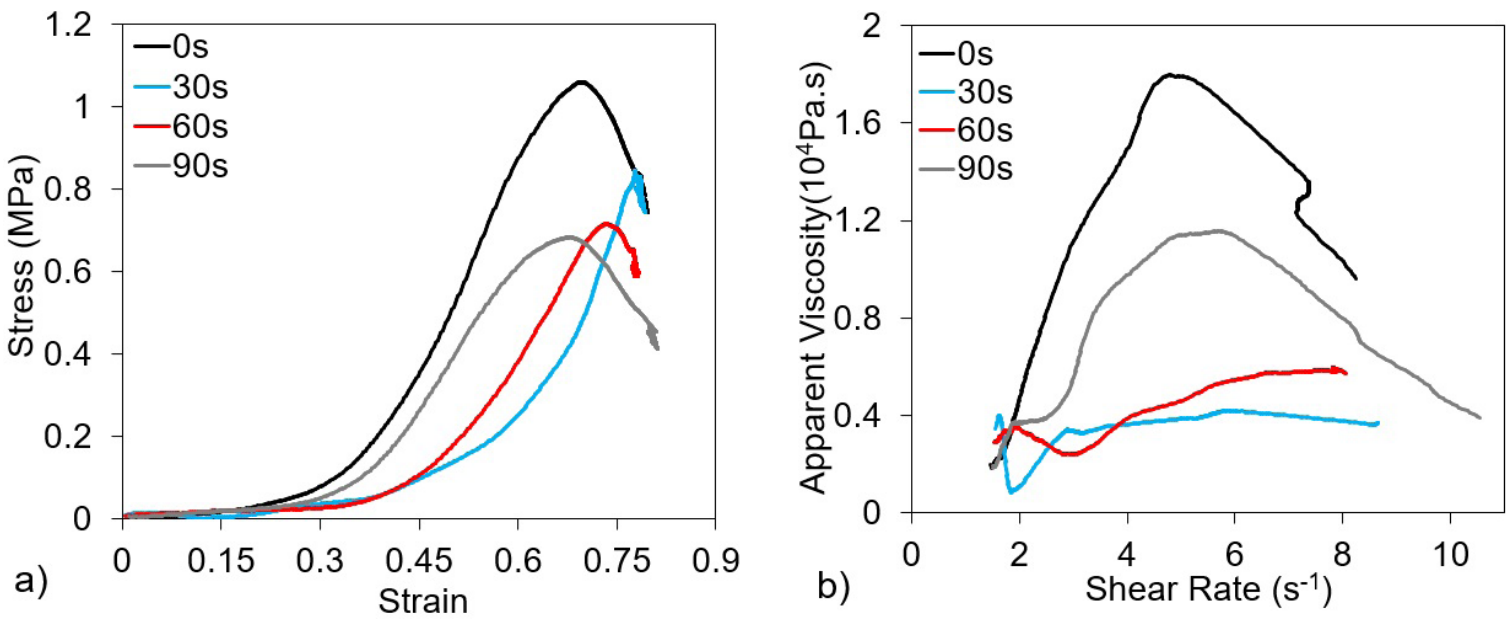

Figure 9. Engineering stress vs. engineering strain (a) and apparent viscosity vs. shear rate (b) curves measured during thixoforming (open-die forging) of $\mathrm{A} 15 \mathrm{Si} 5 \mathrm{Zn} 0.5 \mathrm{Mg}$ alloy after heat treatment at $594{ }^{\circ} \mathrm{C}$ for $0,30,60$ and $90 \mathrm{~s}$.

Table 4. Rheological parameters at the point of maximum apparent viscosity (beginning of dendritic breakdown) and point of maximum stress (end of dendritic breakdown) for heat-treated samples of $\mathrm{A} 15 \mathrm{Si} 5 \mathrm{Zn} 0.5 \mathrm{Mg}$ alloy during thixoforming.

\begin{tabular}{|c|c|c|c|c|}
\hline Point & \multicolumn{2}{|c|}{$\mu_{\max }$} & \multicolumn{2}{|c|}{$\sigma_{\max }$} \\
\hline Holding time (s) & $\mu\left(10^{4} \mathrm{~Pa} . \mathrm{s}\right)$ & $\dot{\gamma}\left(\mathrm{s}^{-1}\right)$ & $\sigma(\mathrm{MPa})$ & $\varepsilon$ \\
\hline 0 & 1.79 & 4.7 & 1.06 & 0.69 \\
\hline 30 & 0.41 & 5.8 & 0.84 & 0.77 \\
\hline 60 & 0.59 & 7.8 & 0.71 & 0.73 \\
\hline 90 & 1.15 & 5.7 & 0.68 & 0.67 \\
\hline
\end{tabular}


considered suitable for this kind of process in the literature, i.e., $10^{4}$ to $10^{6} \mathrm{~Pa} . \mathrm{s}^{2,45,46}$. Thus, although the microstructure of the alloy is coarse, it appears to have less influence over rheology than does the liquid fraction, higher values of which facilitate movement of solid particles in the slurry (the value of $\mathrm{f}_{1}$ used here was 0.63 ).

\section{Conclusion}

The suitability of an Al-Si-Zn-Mg alloy for thixoforming was analyzed. The results reveal good agreement between the thermodynamic behavior predicted by DSC and CALPHAD and the data obtained from semisolid forging of samples of the alloy. Although the alloy has a coarse microstructure $\left(\mathrm{G}_{\mathrm{S}}{ }^{\max }=200 \mu \mathrm{m}\right)$, its rheological behavior is appropriate for thixoforming $\left(\sigma_{\max }=1.06 \mathrm{MPa}\right.$ and $\left.\mu_{\max }=1.79 \times 10^{4} \mathrm{~Pa} . \mathrm{s}\right)$, indicating that the microstructure only plays a secondary role in determining viscosity when enough liquid $\left(f_{1}=0.63\right)$ is present in the slurry to enhance the flow. The alloy was therefore considered suitable for use as potential raw material for semisolid processing.

\section{Acknowledgments}

The authors would like to thank the Brazilian research funding agencies FAPESP (São Paulo Research Foundation Projects 2013/09961-3 and 2015/22143-3), CNPq (National Council for Scientific and Technological Development - Project PQ 304921/2017-3) and CAPES (Federal Agency for the Support and Improvement of Higher Education) - Finance Code 001) for providing financial support for this study. The authors are also indebted to the Faculty of Mechanical Engineering at the University of Campinas and the Faculty of Mechanical Engineering at University of Oriente for the practical support very kindly provided.

\section{References}

1. Chiarmetta G. Why Thixo? In: 6th International Conference on Semisolid Processing of Alloys and Composites; 2000; Turin, Italy. Proceedings. Turin: Edimet. p. 15-21.

2. NADCA: North American Die Casting Association. Product specification standards for die castings produced by semi-solid and squeeze casting process. 4th ed. Wheeling: NADCA; 2006. 218 p. (Standards, Publication, 403).

3. Zoqui EJ. Alloys for semisolid processing. In: McGeough J. ed. Compreensive materials processing. Vol. 5. Elsevier Ltd; 2014. p. 163-190. https://doi.org/10.1016/B978-0-08-0965321.00520-3.

4. Flemings MC. Behavior of metal alloys in the semisolid state. Metall Trans, A, Phys Metall Mater Sci. 1991;22A:957-81. http://dx.doi.org/10.1007/BF02661090.

5. Sales RC, Felipe P Jr, Paradela KG, Garção WJL, Ferreira AF. Effect of Solidification processing parameters and silicon content on the dendritic spacing and hardness in hypoeutectic Al-Si Alloys. Mater Res. 2018;21(6):e20180333. http://dx.doi. org/10.1590/1980-5373-mr-2018-0333.

6. Davies JR. Aluminum and aluminum Alloys. 1st ed. Ohio: ASM International; 1993. p. 88-121.

7. Otani LB, Matsuo MM, Freitas BJM, Zepon G, Kiminami CS, Botta WJ, et al. Tailoring the microstructure of recycled 319 aluminum alloy aiming at high ductility. J Mater Res Technol. 2019;8(4):3539-49. http://dx.doi.org/10.1016/j.jmrt.2019.06.030.
8. Laukli HI, Gourlay CM, Dahle AK. Migration of crystals during the filling of semi-solid castings. Metall Mater Trans, A Phys Metall Mater Sci. 2005;36A(13):805-18. http://dx.doi. org/10.1007/s11661-005-1011-5.

9. Wang G, Huang H, Yang Z, Shi X, He X. Numerical simulation on the die filling process of the Thixo-Forging of Al-7 wt pct Si/Al-22 wt pet Si Bimetal composite. Metall Mater Trans, A Phys Metall Mater Sci. 2015;46A(5):2121-8. http://dx.doi. org/10.1007/s11663-015-0404-0.

10. Ming L, Yuan-Dong L, Wen-Long Y, Yu Z, Zong-Gang W. Effects of forming processes on microstructures and mechanical properties of A356 Aluminum Alloy Prepared by Self-inoculation Method. Mater Res. 2019;2(3):e20180698. http://dx.doi. org/10.1590/1980-5373-MR-2018-0698.

11. Li M, Li Y, Zhou H. Effects of pouring temperature on microstructure and mechanical properties of the A356 aluminum alloy diecastings. Mater Res. 2020;23(1):e20190676. http:// dx.doi.org/10.1590/1980-5373-MR-2019-0676.

12. Reisi M, Niroumand B. Growth of primary particles during secondary cooling of a rheocast alloy. J Alloys Compd. 2009;475:643-7. http://dx.doi.org/10.1016/j.jallcom.2008.07.090.

13. Lashkari O, Ghomashchi R. The implication of rheology in semi-solid metal processes: An overview. J Mater Process Technol. 2007;182:229-40. http://dx.doi.org/10.1016/j. jmatprotec.2006.08.003.

14. Perez M, Barbé JC, Neda Z, Bréchet Y, Salvo L. Computer simulation of the microstructure and rheology of semi-solid alloys under shear. Acta Mater. 2000;48:3773-82. http://dx.doi. org/10.1016/S1359-6454(00)00161-0.

15. Liu D, Atkinson HV, Jones H. Thermodynamic prediction of thixoformability in alloys based on the $\mathrm{Al}-\mathrm{Si}-\mathrm{Cu}$ and $\mathrm{Al}-\mathrm{Si}-$ $\mathrm{Cu}-\mathrm{Mg}$ systems. Acta Mater. 2005;53:3807-19. http://dx.doi. org/10.1016/j.actamat.2005.04.028.

16. Zoqui EJ, Benati DM, Proni CTW, Torres LV. Thermodynamic evaluation of the thixoformability of Al-Si alloys. Calphad. 2016;52:98-109. http://dx.doi.org/10.1016/j.calphad.2015.12.006.

17. Cheng S, Hou H, Zhao Y, Jin Y. Effect of process parameters on the microstructure of semi-solid ZL101 aluminum alloy. Mater Res. 2016;19(3):555-61. http://dx.doi.org/10.1590/1980-5373MR-2015-0567.

18. Zoqui EJ, Torres LV. Evaluation of the thixoformability of AA7004 and AA7075 alloys. Mater Res. 2010;13(3):305-18. http://dx.doi.org/10.1590/S1516-14392010000300006.

19. Proni CTW, Torres LV, Haghayeghi R, Zoqui EJ. ECAP: An alternative route for producing AlSiCu for use in SSM processing. Mater Charact. 2016;118:252-62. http://dx.doi.org/10.1016/j. matchar.2016.06.002.

20. Paes M, Zoqui EJ. Semi-solid behavior of new Al-Si-Mg alloys for thixoforming. Mater Sci Eng A. 2005;406A:63-73. http:// dx.doi.org/10.1016/j.msea.2005.07.018.

21. Nadal RL, Roca AS, Fals HDC, Zoqui EJJ. Mechanical properties of thixoformed hypoeutectic gray cast iron. J Mater Process Technol. 2015;226:146-56. http://dx.doi.org/10.1016/j. jmatprotec.2015.07.015.

22. Haghayeghi R, Zoqui EJ, Timelli G. Enhanced refinement and modification via self-inoculation of Si phase in a hypereutectic aluminium alloy. J Mater Process Technol. 2018;252:294-303. http://dx.doi.org/10.1016/j.jmatprotec.2017.09.032.

23. Roca AS, Fals HDC, Pedron JA, Zoqui EJ. Thixoformability of hypoeutectic gray cast iron. J Mater Process Technol. 2012;212:1225 35. http://dx.doi.org/10.1016/j.jmatprotec.2012.01.012.

24. Campo KN, Zoqui EJ. Thixoforming of an ECAPed Aluminum A356 Alloy: Microstructure evolution, rheological behavior, and mechanical properties. Metall Mater Trans, A Phys Metall Mater Sci. 2016;47A(4):1792-802. http://dx.doi.org/10.1007/ s11661-016-3339-4.

25. Brollo GL, Proni CTW, de Paula LC, Zoqui EJ. An alternative method to identify critical temperatures for semisolid materials 
process applications using differentiation. Thermochim Acta. 2017;651:22-33. http://dx.doi.org/10.1016/j.tca.2017.02.010.

26. Brollo GL, de Paula LC, Proni CTW, Zoqui EJ. Analysis of the thermodynamic behavior of $\mathrm{A} 355$ and $\mathrm{B} 319$ alloys using the differentiation method. Thermochim Acta. 2018;659:121-35. http://dx.doi.org/10.1016/j.tca.2017.11.011.

27. Flynn JH. Analysis of DSC results by integration. Thermochim Acta. 1993;217:29-149. http://dx.doi.org/10.1016/00406031(93)85104-H.

28. Nafisi S, Emadi D, Ghomashchi R. Semi solid metal processing: The fraction solid dilemma. Mater Sci Eng A. 2009;507A:8792. http://dx.doi.org/10.1016/j.msea.2008.11.052.

29. Kazakov AA, Luong NH. Characterization of semisolid materials structure. Mater Charact. 2001;46:155-61. http:// dx.doi.org/10.1016/S1044-5803(01)00118-8.

30. Zoqui EJ, Shehata MT, Paes M, Kao V, Es-Sadiqi E. Morphological evolution of SSM A356 during partial remelting. Mater Sci Eng A. 2002;325A:38-53. http://dx.doi.org/10.1016/S09215093(01)01401-0.

31. ASTM International. E112-13 Standard Test Methods for Determining Average Grain Size. West Conshohocken, PA: ASTM International; 2013. https://doi.org/10.1520/E0112-13

32. Proni CTW, Zoqui EJ. The effect of heating rate on the microstructural breakdown required for thixoformability. Int J Mater Res. 2017;108:228-36. http://dx.doi.org/10.3139/146.111472.

33. Laxmanan V, Flemings MC. Deformation of semi-solid Sn-15 Pct Pb alloy. Metall Mater Trans, A Phys Metall Mater Sci. 1980;11A:1927-37. http://dx.doi.org/10.1007/BF02655112.

34. Brollo GL, Tamayo DV, Torres LV, Zoqui EJ. Thermodynamic evaluation of the thixoformability of Al-Si-Cu alloys. Calphad. 2019;67:101671. http://dx.doi.org/10.1016/j.calphad.2019.101671.

35. Irizalp SG, Saklakoglu N. Effect of Fe-rich intermetallics on the microstructure and mechanical properties of thixoformed A380 aluminum alloy. Engineering Science and Technology International. 2014;17:58-62. http://dx.doi.org/10.1016/j. jestch.2014.03.006.

36. Tillová E, Chalupová M, Hurtalová L. [Internet]. Evolution of phases in a recycled Al-Si cast alloy during solution treatment. Rijeka: InTech; 2018 [cited 2018 Mar 8]. Available from: https:// www.intechopen.com/books/scanning-electron-microscopy/ evolution-of-phases-in-a-recycled-al-si-cast-alloy-duringsolution-treatment
37. Warmuzek M. Metallographic techniques for aluminum and its alloys. In: Voort GFV, editor. Metallography and Microstructures. Vol. 9, 1st ed. Ohio: ASM International Materials Park; 2004. p. 711-775.

38. Prados EF, Sordi VL, Ferrante M. The effect of $\mathrm{Al}_{2} \mathrm{Cu}$ precipitates on the microstructural evolution, tensile strength, ductility and work-hardening behaviour of a Al-4 wt.\% Cu alloy processed by equal-channel angular pressing. Acta Mater. 2013;61:115-25. http://dx.doi.org/10.1016/j.actamat.2012.09.038.

39. Zhang X, Chen T. Solution treatment behaviors of 6061 aluminum alloy prepared by powder thixoforming. Mater Res. 2018;21(4):e20180057. http://dx.doi.org/10.1590/1980-5373MR-2018-0057.

40. Jorstad JL, Pan QY, Apelian D. Solidification microstructure affecting ductility in semi-solid-cast products. Mater Sci Eng A. 2005;413-414:186-91. http://dx.doi.org/10.1016/j. msea.2005.09.026.

41. Gao T, Hu K, Wang L, Zhang B, Liu X. Morphological evolution and strengthening behavior of $\alpha-\mathrm{Al}(\mathrm{Fe}, \mathrm{Mn}) \mathrm{Si}$ in $\mathrm{Al}-6 \mathrm{Si}-2 \mathrm{Fe}-$ xMn alloys. Results Physics. 2017;7:1051-4. http://dx.doi. org/10.1016/j.rinp.2017.02.040.

42. Warng PS, Liauh YL, Lee SL, Lin JC. Effects of Be addition on microstructures and mechanical properties of B319.0 alloys. Mater Chem Phys. 1998;53:195-202. http://dx.doi.org/10.1016/ S0254-0584(98)00007-8.

43. Martinez R, Russier V, Couzinier JP, Guillot I, Cailletaud G. Modeling of the influence of coarsening on viscoplastic behavior of a 319 foundry aluminum alloy. Mater Sci Eng A. 2013;559A:40-8. http://dx.doi.org/10.1016/j.msea.2012.07.096.

44. Li M, Li Y, Zhou H. Effects of pouring temperature on microstructure and mechanical properties of the A356 aluminum alloy diecastings. Mater Res. 2020;23(1):e20190676. http:// dx.doi.org/10.1590/1980-5373-MR-2019-0676.

45. Flemings MC. Coarsening in solidification processing. Mater Trans. 2005;46(5):895-900. http://dx.doi.org/10.2320/ matertrans.46.895.

46. Jiang J, Wang Y, Atkinson HV. Microstructural coarsening of 7005 aluminum alloy semisolid billets with high solid fraction. Journal of Materials Characterization. 2014;90:52-61. http:// dx.doi.org/10.1016/j.matchar.2014.01.017. 